\title{
Hubungan Tingkat Pengetahuan Dengan Kepatuhan Minum Obat Pada Pasien Hipertensi Di Rumah Sakit X Cilacap
}

\author{
Nia Indriana ${ }^{1}$, Mika Tri Kumala Swandari ${ }^{2 *}$, Yuniariana Pertiwi ${ }^{3}$ \\ 1,2,3 Program Studi Farmasi, STIKES Al-Irsyad Al-Islamiyyah Cilacap, Jawa Tengah, Indonesia \\ e-mail correspondance:*michakumala@yahoo.com
}

\begin{abstract}
ABSTRAK
Hipertensi merupakan tekanan darah persisten dimana tekanan sistoliknya $\geq 140 \mathrm{mmHg}$ dan tekanan diastolik $\geq 90 \mathrm{mmHg}$. Pengetahuan tentang penyakit yang diderita dapat berpengaruh pada kepatuhan pasien dalam pengobatan terutama dalam minum obat dan memberikan outcome yang optimal. Penelitian ini bertujuan untuk mengetahui penilaian kepatuhan minum obat pada pasien hipertensi dan mengetahui tingkat pengetahuan tentang hipertensi dengan kepatuhan minum obat. Metode yang digunakan dalam penelitian ini adalah metode non-eksperimen yang bersifat deskriptif dengan pendekatan cross sectional. Teknik analisis data dalam kegiatan ini disajikan dalam bentuk analisis deskriptif dan analisis bivariat. Pengukuran tingkat pengetahuan dengan kepatuhan menggunakan uji statistik chi square dengan $\alpha=0,05$. Pengukuran tingkat kepatuhan minum obat dengan menggunakan kuisioner Morisky Medication Adherance Scale (MMAS-8). Berdasarkan hasil pengukuran tingkat pengetahuan dari 79 responden terdapat 70 responden $(88,6 \%)$ memiliki tingkat pengetahuan yang baik, 8 responden $(10,1 \%)$ memiliki tingkat pengetahuan yang cukup dan 1 responden (1,3\%) memiliki tingkat pengetahuan yang buruk. Pengukuran tingkat kepatuhan minum obat dari 79 responden terdapat 36 responden (45,6\%) memiliki kepatuhan minum obatnya tinggi, 29 responden (36,7\%) memliki tingkat kepatuhan minum obatnya sedang dan 14 responden $(17,7 \%)$ memiliki tingkat kepatuhan minum obatnya rendah. Hubungan antara tingkat pengetahuan dengan kepatuhan minum obat pada pasien hipertensi di Rumah Sakit X Cilacap yaitu terdapat hubungan antara tingkat pengetahuan dengan kepatuhan minum obat (p value 0,005 <0,05).
\end{abstract}

Keyword: Hipertensi, tingkat pengetahuan, kepatuhan minum obat, Cilacap

\begin{abstract}
Hypertension is a persistent blood pressure where systolic pressure $\geq 140 \mathrm{mmHg}$ and diastolic pressure $\geq 90 \mathrm{mmHg}$. Knowledge about the illness can affect patient compliance in treatment, especially in taking medication and provide optimal outcomes. This study aims to determine the assessment of medication adherence in hypertensive patients and determine the level of knowledge about hypertension with medication adherence. The method used in this study is a descriptive non-experimental method with a cross sectional approach. Data analysis techniques in this activity are presented in the form of descriptive analysis and bivariate analysis. Measurement of the level of knowledge with compliance using the chi square statistical test with $\alpha=0.05$. Measurement of medication adherence level using the Morisky Medication Adherance Scale (MMAS-8) questionnaire. Based on the results of measurement of the level of knowledge of 79 respondents there were 70 respondents (88.6\%) had a good level of knowledge, 8 respondents (10.1\%) had a sufficient level of knowledge and 1 respondent (1.3\%) had a poor level of knowledge. Measuring the level of medication adherence from 79 respondents there were 36 respondents (45.6\%) had high medication adherence, 29 respondents (36.7\%) had moderate levels of medication adherence and 14 respondents (17.7\%) had levels of adherence the cure is low. The relationship between the level of knowledge and medication adherence in hypertensive patients at Cilacap Hospital $X$ is the relationship between the level of knowledge and medication adherence ( $p$ value $0.005<0.05$ ).
\end{abstract}

Keywords: Hypertension, level of knowledge, medication adherence, Cilacap 


\section{PENDAHULUAN}

Hipertensi merupakan tekanan darah persisten dimana tekanan sistoliknya $\geq 140 \mathrm{mmHg}$ dan tekanan diastolik $\geq 90 \mathrm{mmHg}[1]$. Menurut data WHO (World Health Organization) tahun 2015 menunjukkan sekitar 1,13 miliar orang didunia menyandang hipertensi, artinya 1 dari 3 orang di dunia terdiagnosa hipertensi[2]. Berdasarkan angka kejadian penyakit di Kabupaten Cilacap menurut Dinas Kesehatan Kabupaten Cilacap tahun 2014, hipertensi termasuk 10 penyakit terbanyak. Kasus hipertensi di Kabupaten Cilacap tahun 2014 yaitu sebanyak 15.717 kasus dengan hipertensi essensial 13.105 kasus, sedangkan pada tahun 2015 jumlah kasus hipertensi di Kabupaten Cilacap sebanyak 8.118 kasus [3].

Kepatuhan minum obat pada penderita hipertensi sangat penting karena dengan minum obat antihipertensi secara teratur dapat mengontrol tekanan darah pada penderita hipertensi, sehingga dalam jangka panjang risiko kerusakan organ-organ seperti jantung, ginjal, dan otak dapat dikurangi[3]. Pengetahuan adalah segala apa yang diketahui berdasarkan pengalaman yang didapatkan oleh setiap manusia Tingkat pengetahuan dan pemahaman pasien hipertensi terkait penyakitnya dapat menunjang keberhasilan terapi sehingga tekanan darah pasien dapat terkontrol dengan baik. Semakin pasien memahami penyakitnya, maka pasien akan semakin aware dalam menjaga pola hidup, teratur minum obat, dan tingkat kepatuhan pasien juga akan semakin meningkat[4].

\section{METODE PENELITIAN}

Metode yang digunakan dalam penelitian ini adalah metode non-eksperimen yang bersifat deskriptif dengan pendekatan cross sectional. Penelitian ini dilakukan di Rumah Sakit X Cilacap pada bulan Maret 2020. Untuk pengumpulan data yang dilakukan dengan menggunakan data rekam medik yang ada di Rumah Sakit X Cilacap. Pengumpulan data dilakukan dengan menggunakan kuisioner tingkat pengetahuan hipertensi dan kuisioner Morisky Medication Adherance Scale (MMAS-8) untuk tingkat kepatuhan minum obat hipertensi yang telah valid. Adapun teknik analisis data dalam kegiatan ini disajikan dalam bentuk analisis deskriptif dan analisis bivariat. Data yang diperoleh diolah dengan menghitung persentase dari jumlah pasien. Pengukuran tingkat pengetahuan dengan kepatuhan menggunakan uji statistik chi squre dengan $\alpha=0,05$.

\section{HASIL DAN PEMBAHASAN}

\section{Data Kategori dan Analisis Uji Statistik Bivariat}

\section{Jenis Kelamin}

Tabel. 1 Distribusi Persebaran Responden Berdasarkan Jenis Kelamin Di Rumah Sakit X

\begin{tabular}{ccc}
\multicolumn{3}{c}{ Cilacap } \\
\hline Jenis Kelamin & Frekuensi & Persen \\
\hline Laki-laki & 35 & 44,3 \\
Perempuan & 44 & 55,7 \\
\hline Total & 79 & 100,0 \\
\hline
\end{tabular}

Pada tabel 1. Menunjukkan bahwa karakteristik dari 79 responden di Rumah Sakit X Cilacap responden yang lebih banyak menderita hipertensi sebagian besar berjenis kelamin perempuan yaitu sebanyak 44 resonden $(55,7 \%)$. Berdasarkan data riskesdas tahun 2018 untuk pasien hipertensi juga lebih banyak perempuan dibandingkan dengan pria yaitu perempuan $36,9 \%$ sedangkan pria $31,3 \%$.

Jenis kelamin berpengaruh pada terjadinya penyakit hipertensi. Pada jenis kelamin perempuan yang telah memasuki menopause, pravalensi hipertensi pada perempuan 
meningkat. Bahkan setelah usia 65 tahun, hipertensi pada perempuan lebih tinggi dibandingkan dengan pria karena faktor hormonal[5].

Tabel.2 Jenis Kelamin Dengan Tingkat Pengetahuan

\begin{tabular}{|c|c|c|c|c|c|c|c|c|}
\hline \multirow{3}{*}{ Jenis Kelamin } & \multicolumn{8}{|c|}{ Tingkat Pengetahuan } \\
\hline & \multicolumn{2}{|c|}{ Baik } & \multicolumn{2}{|c|}{ Cukup } & \multicolumn{2}{|c|}{ Buruk } & \multicolumn{2}{|c|}{ Total } \\
\hline & $\mathrm{n}$ & $\%$ & $\mathrm{n}$ & $\%$ & $\mathrm{n}$ & $\%$ & $\mathbf{n}$ & $\%$ \\
\hline Laki-laki & 31 & 88,6 & 4 & 11,4 & 0 & 0,0 & 35 & 100 \\
\hline Perempuan & 39 & 88,6 & 4 & 9,1 & 1 & 2,3 & 44 & 100 \\
\hline Total & 70 & 88,6 & 8 & 10,1 & 1 & 1,3 & 79 & 100 \\
\hline
\end{tabular}

Pengetahuan adalah segala apa yang diketahui berdasarkan pengalaman yang didapatkan oleh setiap manusia[6]. Seseorang dalam lingkungannya akan memperoleh pengalaman, dimana pengalaman tersebut salah satu faktor yang dapat mempengaruhi pengetahuan seseorang[7]. Pada tabel 2 menunjukkan bahwa untuk tingkat pengetahuan baik pada responden berjenis kelamin laki-laki sebanyak $31(88,6 \%)$, tingkat pengetahuan cukup sebanyak 4 responden $(11,4 \%)$ sedangkan pada jenis kelamin perempuan untuk tingkat pengetahuan yang baik sebanyak 39 responden $(88,6 \%)$, tingkat pengetahuan yang cukup sebanyak 4 responden $(9,1 \%)$ dan ada 1 responden yang tingkat pengetahuannya buruk.

Tabel 3. Hubungan Antara Jenis Kelamin Dengan Kepatuhan Minum Obat

\begin{tabular}{|c|c|c|c|c|c|c|c|c|c|}
\hline \multirow{3}{*}{$\begin{array}{c}\text { Jenis } \\
\text { Kelamin }\end{array}$} & \multicolumn{8}{|c|}{ Kepatuhan minum obat } & \multirow{3}{*}{ P-value } \\
\hline & \multicolumn{2}{|c|}{ Tinggi } & \multicolumn{2}{|c|}{ Sedang } & \multicolumn{2}{|c|}{ Rendah } & \multicolumn{2}{|c|}{ Total } & \\
\hline & $\mathbf{n}$ & $\%$ & $\mathbf{n}$ & $\%$ & $\mathbf{n}$ & $\%$ & $\mathbf{n}$ & $\%$ & \\
\hline Laki-laki & 15 & 42,9 & 15 & 42,9 & 5 & 14,3 & 35 & 100 & \\
\hline Perempuan & 21 & 47,7 & 14 & 31,8 & 9 & 20,5 & 44 & 100 & 0,558 \\
\hline Total & 36 & 45,6 & 29 & 36,7 & 14 & 17,7 & 79 & 100 & \\
\hline
\end{tabular}

Hasil analisis tabel 3. Menyatakan bahwa dari 44 responden berjenis kelamin perempuan terhadap kepatuhan minum obat tinggi sebanyak 21 responden $(47,7 \%), 14$ responden $(31,8 \%)$ kepatuhan minum obatnya sedang dan 9 responden $(14,3 \%)$ kepatuhan minum obatnya rendah.

Hasil uji statistik diperoleh nilai $p$-value $=0,558(p>0,05)$, maka dapat disimpulkan tidak ada perbedaan proporsi kepatuhan minum obat antara responden berjenis kelamin laki-laki dan perempuan terhadap kepatuhan minum obat (tidak ada hubungan yang signifikan jenis kelamin dengan kepatuhan minum obat). Hasil analisis untuk responden yang berjenis kelamin perempuan mempunyai tingkat kepatuhan minum obatnya tinggi lebih banyak dibandingkan dengan laki-laki karena mayoritas yang berobat adalah perempuan tetapi tidak semua responden yang berjenis kelamin perempuan kepatuhan minum obatnya tinggi.

\section{Usia}

Tabel.4 Distribusi Persebaran Responden Berdasarkan Usia Di Rumah Sakit X Cilacap

\begin{tabular}{ccc}
\hline Usia & Frekuensi & Persen \\
\hline 25-34 tahun & 1 & 1,3 \\
45-54 tahun & 10 & 12,7 \\
55-64 tahun & 40 & 50,6 \\
65-74 tahun & 25 & 31,6 \\
75+ tahun & 3 & 3,8 \\
\hline Total & 79 & 100,0 \\
\hline
\end{tabular}

Berdasarkan usia menurut Riskesdas tahun 2018 hasil analisis pada tabel 4 menunjukkan bahwa, karakteristik dari 79 responden di Rumah Sakit X Cilacap sebagian 
besar berusia 55-64 tahun sebanyak 40 responden $(50,6 \%)$ dan usai paling sedikit yaitu 2534 tahun sebanyak 1 responden $(1,3 \%)$.

Faktor usia adalah salah satu faktor risiko yang dapat mempengaruhi hipertensi, oleh sebab itu dengan bertambahnya usia maka semakin tinggi risiko mendapatkan hipertensi[8]. Berdasarkan teori tekanan darah umumnya mengalami peningkatan dimulai setelah usia 40 tahun dikarenakan arteri akan mengalami penebalan sehingga pembuluh darah akan menyempit dan diikuti oleh penurunan elastisitas pembuluh darah sehingga pembuluh darah menjadi kaku[9].

Tabel 5. Usia Dengan Tingkat Pengetahuan

\begin{tabular}{ccccccccc}
\hline \multirow{2}{*}{ Usia } & \multicolumn{8}{c}{ Tingkat Pengetahuan } \\
\cline { 2 - 9 } & \multicolumn{2}{c}{ Baik } & \multicolumn{2}{c}{ Cukup } & \multicolumn{2}{c}{ Buruk } & \multicolumn{2}{c}{ Total } \\
\cline { 2 - 9 } & $\mathbf{n}$ & $\mathbf{0}$ & $\mathbf{n}$ & $\mathbf{\%}$ & $\mathbf{n}$ & $\mathbf{\%}$ & $\mathbf{N}$ & $\mathbf{\%}$ \\
\hline 25-34 tahun & 1 & 100 & 0 & 0,0 & 0 & 0,0 & 1 & 100 \\
45-54 tahun & 9 & 90,0 & 1 & 10,0 & 0 & 0,0 & 10 & 100 \\
55-64 tahun & 33 & 82,5 & 6 & 15,0 & 1 & 2,5 & 40 & 100 \\
65-74 tahun & 24 & 96,0 & 1 & 4,0 & 0 & 0,0 & 25 & 100 \\
75+ tahun & 3 & 100 & 0 & 0,0 & 0 & 0,0 & 3 & 100 \\
\hline Total & 70 & 88,6 & 8 & 10,1 & 1 & 1,3 & 79 & 100 \\
\hline
\end{tabular}

Pada tabel 5. Tingkat pengetahuan pada usia 55-64 yang berpengetahuan baik sebanyak 33 responden $(82,5 \%), 6$ responden $(15,0 \%)$ berpengetahuan cukup dan terdapat 1 responden yang berpengetahuan buruk. Menurut Notoatmodjo (2003), umur merupakan salah satu faktor yang mempengaruhi pembentukan pengetahuan, makin tua umur seseorang makin konstruktif terhadap masalah yang dihadapi. Menurut observasi yang peneliti lakukan banyak ditemukan pasien hipertensi yang memiliki pengetahuan yang baik tetapi tidak diiringi dengan sikap yang positif, itu yang menyebabkan banyak terjadi penyakit hipertensi primer diumur $<40$ tahun[7].

Tabel 6. Hubungan Antara Usia Dengan Kepatuhan Minum Obat

\begin{tabular}{|c|c|c|c|c|c|c|c|c|c|}
\hline \multirow{3}{*}{ Usia } & \multicolumn{8}{|c|}{ Kepatuhan minum obat } & \multirow{3}{*}{ P-value } \\
\hline & \multicolumn{2}{|c|}{ Tinggi } & \multicolumn{2}{|c|}{ Sedang } & \multicolumn{2}{|c|}{ Rendah } & \multicolumn{2}{|c|}{ Total } & \\
\hline & n & $\%$ & $\mathbf{n}$ & $\%$ & n & $\%$ & 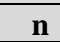 & $\%$ & \\
\hline $25-34$ tahun & 1 & 100 & 0 & 0,0 & 0 & 0,0 & 1 & 100 & \\
\hline 45-54 tahun & 5 & 50,0 & 3 & 30,0 & 2 & 20,0 & 10 & 100 & \\
\hline 55-64 tahun & 17 & 42,5 & 15 & 37,5 & 8 & 20,0 & 40 & 100 & 0,675 \\
\hline 65-74 tahun & 10 & 40,0 & 11 & 44,0 & 4 & 16,0 & 25 & 100 & \\
\hline $75+$ tahun & 3 & 100 & 0 & 0,0 & 0 & 0,0 & 3 & 100 & \\
\hline Total & 36 & 45,6 & 29 & 36,7 & 14 & 17,7 & 79 & 100 & \\
\hline
\end{tabular}

Pada tabel 6. Menunjukkan bahwa usia yang paling banyak adalah 55-64 tahun sebanyak 40 responden. Hasil uji statistik diatas diperoleh nilai $p$-value $=0,675(p>0,05)$ yaitu tidak ada hubungan yang signifikan antara usia dengan tingkat kepatuhan minum obat antihipertensi. Seseorang yang mengalami pertumbuhan usia akan mengalami frustasi atau sikap penolakan terhadap penyakitnya sehingga akan mengalami sikap yang tidak patuh terhadap anjuran dokter ataupun apoteker/terapi yang diberikan oleh dokter/tim medis[10].

\section{Pekerjaan}

Tabel.7 Distribusi Persebaran Responden Berdasarkan Pekerjaan Di Rumah Sakit X Cilacap

\begin{tabular}{ccc}
\hline Pekerjaan & Frekuensi & Persen \\
\hline Peg.Swasta & 2 & 2,5 \\
Wiraswasta & 1 & 1,3 \\
Pensiunan & 42 & 53,2 \\
Ibu Rumah Tangga & 32 & 40,5 \\
Lain-lain & 2 & 2,5 \\
\hline Total & 79 & 100,0 \\
\hline
\end{tabular}


Hasil analisis pada tabel 7. Menunjukkan bahwa karakteristik dari 79 responden di Rumah Sakit X Cilacap, pekerjaan yang paling banyak yaitu pensiunan dan ibu rumah tangga. Pada pensiunan sebanyak 42 responden $(53,2 \%)$, dari hasil wawancara dengan responden kebanyakan responden setelah pensiun jarang melakukan aktifitas fisik seperti berolahraga. Hipertensi rentan berisiko dengan pola hidup yang kurang bergerak/aktifitas dalam kehidupan sehari-hari[11].

Pada pekerjaan ibu rumah tangga sebanyak 32 responden (40,5\%). Pekerjaan ibu rumah tangga mempunyai aktivitas fisik yang lebih ringan sehingga memiliki faktor risiko terkena hipertensi lebih tinggi dan dimungkinkan ada faktor risiko lain seperti stress yang dapat memicu terjadinya peningkatan aktivitas saraf simpatis sehingga tekanan darah menjadi presisten lebih tinggi dari biasanya[1].

Tabel 8. Pekerjaan Dengan Tingkat Pengetahuan

\begin{tabular}{|c|c|c|c|c|c|c|c|c|}
\hline \multirow{3}{*}{ Pekerjaan } & \multicolumn{8}{|c|}{ Tingkat pengetahuan } \\
\hline & \multicolumn{2}{|c|}{ Baik } & \multicolumn{2}{|c|}{ Cukup } & \multicolumn{2}{|c|}{ Buruk } & \multicolumn{2}{|c|}{ Total } \\
\hline & $\mathbf{n}$ & $\%$ & $\mathbf{n}$ & $\%$ & $\mathbf{n}$ & $\%$ & $\mathbf{n}$ & $\%$ \\
\hline Peg.swasta & 2 & 100 & 0 & 0,0 & 0 & 0,0 & 2 & 100 \\
\hline Wiraswasta & 1 & 100 & 0 & 0,0 & 0 & 0,0 & 1 & 100 \\
\hline Pensiunan & 39 & 92,9 & 3 & 7,1 & 0 & 0,0 & 42 & 100 \\
\hline Ibu rumahTangga & 27 & 84,4 & 4 & 12,5 & 1 & 3,1 & 32 & 100 \\
\hline Lain-lain & 1 & 50,0 & 1 & 50,0 & 0 & 0,0 & 2 & 100 \\
\hline Total & 70 & 88,6 & 8 & 10,1 & 1 & 1,3 & 79 & 100 \\
\hline
\end{tabular}

Pada tabel 8. Menunjukkan bahwa pekerjaan yang paling banyak adalah pensiunan. Pensiunan memiliki tingkat pengetahuan yang baik sebanyak 39 responden. Pada pasien pensiunan berkaitan dengan tingkat pendidikan, rata-rata untuk tingkat pendidikannya tinggi yaitu SMA dan perguruan tinggi sehingga semakin mudah seseorang menerima informasi dan makin banyak pula pengetahuan yang dimiliki, kemudian pasien yang bekerja sebagai ibu rumah tangga terdapat 1 pasien yang memiliki pengetahuan yang buruk.

Pengetahuan yang buruk juga mempengaruhi tingkat kepatuhan minum obat. Pada penelitian ini untuk responden dengan tingkat pengetahuan buruk tidak ada hubungannya dengan pendidikan karena responden berpendidikan terakhir SMA. Pada saat wawancara, pasien memang tidak begitu mengetahui tentang penyakit hipertensi dan pasien juga sempat berhenti meminum obat antihipertensi dengan mengganti menggunakan obat herbal untuk menurunkan tekanan darahnya.

Tabel 9. Hubungan Antara Pekerjaan Dengan Tingkat Kepatuhan Minum Obat

\begin{tabular}{|c|c|c|c|c|c|c|c|c|c|}
\hline \multirow{3}{*}{ Pekerjaan } & \multicolumn{8}{|c|}{ Kepatuhan minum obat } & \multirow{3}{*}{ P- value } \\
\hline & \multicolumn{2}{|c|}{ Tinggi } & \multicolumn{2}{|c|}{ Sedang } & \multicolumn{2}{|c|}{ Rendah } & \multicolumn{2}{|c|}{ Total } & \\
\hline & $\mathbf{n}$ & $\%$ & $\mathbf{n}$ & $\%$ & $\mathbf{n}$ & $\%$ & $\mathbf{n}$ & $\%$ & \\
\hline Peg.swasta & 2 & 100 & 0 & 0,0 & 0 & 0,0 & 2 & 100 & \\
\hline Wiraswasta & 0 & 0,0 & 0 & 0,0 & 1 & 100 & 1 & 100 & \\
\hline Pensiunan & 20 & 47,6 & 17 & 40,5 & 5 & 11,9 & 42 & 100 & 0,225 \\
\hline Ibu rumah & 14 & 43,8 & 11 & 34,4 & 7 & 21,9 & 32 & 100 & \\
\hline Tangga & & & & & & & & & \\
\hline Lain-lain & 0 & 0,0 & 1 & 50,0 & 1 & 50,0 & 2 & 100 & \\
\hline Total & 36 & 45,6 & 29 & 36,7 & 14 & 17,7 & 79 & 100 & \\
\hline
\end{tabular}

Hasil analisis dari tabel 9. Menyatakan bahwa dari 79 responden pasien yang paling banyak adalah pensiunan sebanyak 42 responden. Dari hasil uji statistik diatas diperoleh nilai $p$-value $=0,225(p>0,05)$, bahwa tidak ada hubungan yang signifikan antara pekerjaan dengan kepatuhan minum obat antihipertensi. Pada penelitian ini responden yang tidak bekerja (pensiunan dan ibu rumah tangga) untuk tingkat kepatuhan minum obatnya tidak semuanya baik, pada saat wawancara kebanyakan pasien seriung lupa membawa obat saat berpergian dan lupa meminum obat karena tidak ada yang mengingatkan. 


\section{Pendidikan}

Tabel.10 Distribusi Persebaran Responden Berdasarkan Pendidikan Di Rumah Sakit X Cilacap

\begin{tabular}{ccc}
\hline Pendidikan & Frekuensi & Persen \\
\hline SD & 5 & 6,3 \\
SMP & 9 & 11,4 \\
SMA & 37 & 46,8 \\
Perguruan Tinggi & 28 & 35,4 \\
\hline Total & 79 & 100,0 \\
\hline
\end{tabular}

Pada tabel 10. Menunjukkan bahwa responden dengan pendidikan terakhir paling banyak yaitu SMA, sebanyak 37 responden (46,8\%). Berdasarkan RISKESDAS (2018), menyatakan bahwa penderita hipertensi lebih banyak terjadi pada kelompok yang memiliki tingkat pendidikan rendah. Tingkat pendidikan yang rendah sangat berisiko untuk tidak patuh dalam menjalani pengobatan karena faktor minimnya pengetahuan yang dimiliki. Tetapi ada yang menyebutkan bahwa semakin tinggi pendidikan seseorang, maka akan memudahkan seseorang menerima informasi sehingga meningkatkan kualitas hidup dan menambah luas pengetahuan. Psikososial meliputi sikap pasien terhadap tenaga kesehatan serta menerima terhadap penyakitnya. Sikap seseorang terhadap perilaku kepatuhan menentukan tingkat kepatuhan [12].

Tabel.11 Pendidikan Dengan Tingkat Pengetahuan

\begin{tabular}{llccccccc}
\hline \multirow{2}{*}{ Pendidikan } & \multicolumn{7}{c}{ Tingkat Pengetahuan } \\
\cline { 2 - 10 } & \multicolumn{2}{c}{ Baik } & \multicolumn{7}{c}{ Cukup } & Buruk & Total \\
\cline { 2 - 10 } & n & \% & n & \% & n & \% & N & \% \\
\hline SD & 4 & 80,0 & 1 & 20,0 & 0 & 0,0 & 5 & 100 \\
SMP & 9 & 100 & 0 & 0,0 & 0 & 0,0 & 9 & 100 \\
SMA & 31 & 83,8 & 5 & 13,5 & 1 & 2,7 & 37 & 100 \\
Perguruan Tinggi & 26 & 92,9 & 2 & 7,1 & 0 & 0,0 & 28 & 100 \\
\hline Total & 70 & 88,6 & 8 & 10,1 & 1 & 1,3 & 79 & 100 \\
\hline
\end{tabular}

Pada tabel 11. Menunjukkan bahwa yang berpendidikan tinggi (SMA, perguruan tinggi) untuk tingkat pengetahuan baik tentang hipertensi untuk tingkat pendidikan terakhir SMA sebanyak 31 responden, 5 responden berpengetahuan cukup, dan terdapat 1 responden berpengetahuan buruk, sedangkan tingkat pengetahuan baik pada pendidikan terakhir perguruan tinggi sebanyak 26 responden dan 2 responden berpengetahuan cukup, tetapi pada penelitian ini untuk tingkat pendidikan rendah untuk tingkat pengetahuannya juga baik, karena dikaitkan dengan pasien yang menderita hipertensi rata-rata sudah hampir 1-5, jadi pengetahuan responden tentang penyakit yang diderita (hipertensi) sudah cukup mengetahui.

Tabel 12. Hubungan Antara Pendidikan Dengan Tingkat Kepatuhan Minum Obat

\begin{tabular}{|c|c|c|c|c|c|c|c|c|c|}
\hline \multirow{3}{*}{ Pendidikan } & \multicolumn{8}{|c|}{ Kepatuhan minum obat } & \multirow[b]{3}{*}{ P-value } \\
\hline & \multicolumn{2}{|c|}{ Tinggi } & \multicolumn{2}{|c|}{ Sedang } & \multicolumn{2}{|c|}{ Rendah } & \multicolumn{2}{|c|}{ Total } & \\
\hline & $\mathrm{n}$ & $\%$ & $\mathbf{n}$ & $\%$ & $\mathrm{n}$ & $\%$ & $\mathrm{n}$ & $\%$ & \\
\hline $\mathrm{SD}$ & 1 & 20,0 & 2 & 40,0 & 2 & 40,0 & 5 & 100 & \multirow{4}{*}{0,524} \\
\hline SMP & 5 & 55,6 & 4 & 44,4 & 0 & 0,0 & 9 & 100 & \\
\hline SMA & 16 & 43,2 & 15 & 40,5 & 6 & 16,2 & 37 & 100 & \\
\hline Perguruan Tinggi & 14 & 50,0 & 8 & 28,6 & 6 & 21,4 & 28 & 100 & \\
\hline Total & 36 & 45,6 & 29 & 36,7 & 14 & 17,7 & 79 & 100 & \\
\hline
\end{tabular}

Pada tabel 11. Menunjukkan bahwa pada penelitian ini responden dengan pendidikan terakhir paling banyak yaitu SMA. Hasil uji statistik diperoleh nilai p-value $=0,524$ (pvalue $>0,05$ ), bahwa tidak ada hubungan yang signifikan antara pendidikan terakhir dengan kepatuhan minum obat antihipertensi. 
Didukung dengan penelitian yang dilakukan oleh [13], menyatakan belum tentu responden yang berpendidikan tinggi mempunyai kepatuhan tinggi dalam menjalani pengobatan, akan tetapi dapat juga responden dengan pendidikan rendah mempunyai kepatuhan tinggi untuk menjalani pengobatan. Jika seseorang yang mempunyai pengetahuan baik tentang penyakit hipertensi maka penderita hipertensi akan berusaha sebisa mungkin menghindari komplikasi dari hipertensi dengan meluangkan waktu untuk rutin pergi ke puskesmas dan mengkonsumsi obat secara teratur [3].

\section{Lama Menderita Hipertensi}

Tabel.13 Distribusi Persebaran Responden Berdasarkan Lama Menderita Hipertensi Di Rumah Sakit X Cilacap

\begin{tabular}{ccc}
\hline Lama Menderita Hipertensi & Frekuensi & Persen \\
\hline 2-6 bulan & 6 & 7,6 \\
$7-11$ bulan & 3 & 3,8 \\
1-5 tahun & 25 & 31,6 \\
6-10 tahun & 22 & 27,8 \\
$>10$ tahun & 23 & 29,1 \\
\hline Total & 79 & 100,0 \\
\hline
\end{tabular}

Lama menderita pasien hipertensi sangat mendukung terhadap pengetahuan dalam penggunaan obat. Faktor yang mempengaruhi pengetahuan seseorang adalah pengalaman dan tingkat pendidikan. Semakin lama seseorang menderita hipertensi maka pengalamannya terhadap penyakit tersebut akan bertambah pula. Pengalaman akan turut memperluas pengetahuan seseorang. Semakin banyak pengalaman seseorang, maka semakin tinggi juga pengetahuannya[1].

Tabel 14. Lama Menderita Hipertensi Dengan Tingkat Pengetahuan

\begin{tabular}{|c|c|c|c|c|c|c|c|c|}
\hline \multirow{3}{*}{$\begin{array}{c}\text { Lama Menderita } \\
\text { Hipertensi }\end{array}$} & \multicolumn{8}{|c|}{ Tingkat Pengetahuan } \\
\hline & \multicolumn{2}{|c|}{ Baik } & \multicolumn{2}{|c|}{ Cukup } & \multicolumn{2}{|c|}{ Buruk } & \multicolumn{2}{|c|}{ Total } \\
\hline & $\mathbf{n}$ & $\%$ & $\mathbf{n}$ & $\%$ & $\mathbf{n}$ & $\%$ & $\mathbf{n}$ & $\%$ \\
\hline $2-6$ bulan & 6 & 100 & 0 & 0,0 & 0 & 0,0 & 6 & 100 \\
\hline 7-11 bulan & 3 & 100 & 0 & 0,0 & 0 & 0,0 & 3 & 100 \\
\hline $1-5$ tahun & 21 & 84,0 & 3 & 12,0 & 1 & 4,0 & 25 & 100 \\
\hline 6-10 tahun & 20 & 90,9 & 2 & 9,1 & 0 & 0,0 & 22 & 100 \\
\hline$>10$ tahun & 20 & 87,0 & 3 & 13,0 & 0 & 0,0 & 23 & 100 \\
\hline Total & 70 & 88,6 & 8 & 10,1 & 1 & 1,3 & 79 & 100 \\
\hline
\end{tabular}

Pada hasil tabel 13. Menunjukkan bahwa responden yang paling banyak yaitu lama menderita hipertensi sekitar 1-5 tahun. Pada tabel 14. Menunjukkan bahwa responden dengan lama menderita hipertensi 1-5 tahun untuk tingkat pengetahuannya baik sebanyak 21 responden $(84,0 \%), 3$ responden $(12,0 \%)$ berpengetahuan cukup dan terdapat 1 responden $(4,0 \%)$ yang berpengetahuan buruk. Ada yang menyebutkan bahwa semakin lama seseorang menderita hipertensi maka pengalamannya terhadap penyakit tersebut akan bertambah pula.

Pada hasil penelitian ini pada pasien hipertensi yang baru menderita hipertensi 2-6 bulan dan 7-11 bulan untuk tingkat pengetahuannya baik, karena pada pasien tersebut rata-rata untuk tingkat pendidikannya tinggi yaitu (SMA dan perguruan tinggi). Seperti yang sudah dijelaskan pada penjelasan tabel 18, bahwa faktor yang mempengaruhi pengetahuan seseorang adalah pengalaman dan tingkat pendidikan.

Tabel 15. Hubungan antara lama menderita hipertensi dengan kepatuhan minum obat

\begin{tabular}{|c|c|c|c|c|c|c|c|c|c|}
\hline \multirow{3}{*}{$\begin{array}{l}\text { Lama } \\
\text { Menderita } \\
\text { Hipertensi }\end{array}$} & \multicolumn{8}{|c|}{ Kepatuhan minum obat } & \multirow{3}{*}{ P- value } \\
\hline & \multicolumn{2}{|c|}{ Tinggi } & \multicolumn{2}{|c|}{ Sedang } & \multicolumn{2}{|c|}{ Rendah } & \multicolumn{2}{|c|}{ Total } & \\
\hline & $\mathbf{n}$ & $\%$ & n & $\%$ & n & $\%$ & $\mathbf{n}$ & $\%$ & \\
\hline 2-6 bulan & 4 & 66,7 & 1 & 16,7 & 1 & 16,7 & 6 & 100 & \\
\hline 7-11 bulan & 2 & 66,7 & 1 & 33,3 & 0 & 0,0 & 3 & 100 & \\
\hline $1-5$ tahun & 8 & 32,0 & 10 & 40,0 & 7 & 28,0 & 25 & 100 & 0,491 \\
\hline $6-10$ tahun & 12 & 54,5 & 6 & 27,3 & 4 & 18,2 & 22 & 100 & \\
\hline
\end{tabular}




\begin{tabular}{lllllllll}
$>10$ tahun & 10 & 43,5 & 11 & 47,8 & 2 & 8,7 & 23 & 100 \\
\hline Total & 36 & 45,6 & 29 & 36,7 & 14 & 17,7 & 79 & 100 \\
\hline *p-value $<0,05$ & & & & & & & &
\end{tabular}

Pada penelitian ini pasien hipertensi yang paling lama menderita hipertensi yaitu $>10$ tahun terdapat 23 responden yang memiliki tingkat kepatuhan minum obat tinggi sebanyak 10 responden $(43,5 \%)$, kepatuhan minum obatnya sedang 11 responden $(47,8 \%)$, dan kepatuhan minum obatnya rendah 2 responden $(8,7 \%)$. Hasil uji statistik diperoleh nilai pvalue $=0,491(p>0,05)$, bahwa tidak ada hubungan yang signifikan antara lama menderita hipertensi dengan kepatuhan minum obat antihipertensi. Pada penelitian ini tidak semua pasien hipertensi yang sudah lama menderita hipertensi tingkat kepatuhan minum obatnya rendah, justru semakin lama menderita hipertensi semakin patuh untuk meminum obat karena kebanyakan pasien sudah mengetahui penyakit yang dideritanya berdasarkan pengalaman.

Tabel 16. Distribusi Persebaran Responden Berdasarkan Nilai Tingkat Pengetahuan Di

\begin{tabular}{ccc}
\multicolumn{3}{c}{ Rumah Sakit X } \\
\hline Tingkat pengetahuan & Frekuensi & Persen \\
\hline Baik & 70 & 88,6 \\
Cukup & 8 & 10,1 \\
Buruk & 1 & 1,3 \\
\hline Total & 79 & 100,0 \\
\hline
\end{tabular}

Hasil analisis pada tabel 16. Menunjukkan bahwa karakteristik dari 79 responden di Rumah Sakit X untuk nilai tingkat pengetahuan baik sebanyak 70 responden $(88,6 \%)$, pengetahuan cukup sebanyak 8 responden $(10,1 \%)$, dan pengetahuan buruk sebanyak 1 responden $(1,3 \%)$.

Tingkat pengetahuan dan pemahaman pasien hipertensi terkait penyakitnya dapat menunjang keberhasilan terapi sehingga tekanan darah pasien dapat terkontrol dengan baik. Semakin pasien memahami penyakitnya, maka pasien akan semakin aware dalam menjaga pola hidup, teratur minum obat, dan tingkat kepatuhan pasien juga akan semakin meningkat[4].

Tabel.17 Distribusi Persebaran Responden Berdasarkan Nilai Tingkat Kepatuhan Di Rumah Sakit X Cilacap

\begin{tabular}{ccc}
\hline Tingkat Kepatuhan & Frekuensi & Persen \\
\hline Tinggi & 36 & 45,6 \\
Sedang & 29 & 36,7 \\
Rendah & 14 & 17,7 \\
\hline Total & 79 & 100,0 \\
\hline
\end{tabular}

Hasil analisis pada tabel 17, menunjukkan bahwa karakteristik dari 79 responden di Rumah Sakit X Cilacap untuk nilai tingkat kepatuhan tinggi sebanyak 36 responden (45,6\%), kepatuhan sedang sebanyak 29 responden $(36,7 \%)$, dan kepatuhan rendah sebanyak 14 responden $(17,7 \%)$. Penelitian ini sama dengan hasil penelitian (Bianti,2015) terkait kepatuhan minum obat, terdapat penderita yang sudah menyadari konsekuensi dari penyakitnya sehingga patuh dan rutin meminum obat, tetapi ada pula penderita yang tidak rutin meminum obatnya. Terdapat beberapa kategori penderita yang tidak rutin meminum obat, yaitu penderita yang sering malas dan lupa meminum obat, serta penderita yang menghentikan sendiri pengobatannya sewaktu-waktu[14].

Pada hasil wawancara yang dilakukan terdapat beberapa responden yang apabila merasa tekanan darah terkontrol dan kondisi tubuh membaik, pasien berhenti meminum obat antihipertensi. 
Tabel 18. Hubungan antara pengetahuan dengan kepatuhan minum obat

\begin{tabular}{|c|c|c|c|c|c|c|c|c|c|}
\hline \multirow{3}{*}{$\begin{array}{c}\text { Tingkat } \\
\text { pengetahuan }\end{array}$} & \multicolumn{8}{|c|}{ Kepatuhan minum obat } & \multirow[b]{3}{*}{ P-value } \\
\hline & \multicolumn{2}{|c|}{ Tinggi } & \multicolumn{2}{|c|}{ Sedang } & \multicolumn{2}{|c|}{ Rendah } & \multicolumn{2}{|c|}{ Total } & \\
\hline & $\mathrm{n}$ & $\%$ & $\mathrm{n}$ & $\%$ & $\mathbf{N}$ & $\%$ & n & $\%$ & \\
\hline Baik & 36 & 51,4 & 25 & 35,7 & 9 & 12,9 & 70 & 100 & \\
\hline Cukup & 0 & 0,0 & 4 & 50,0 & 4 & 50,0 & 8 & 100 & 0,005 \\
\hline Buruk & 0 & 0,0 & 0 & 0,0 & 1 & 100 & 1 & 100 & \\
\hline Total & 36 & 45,6 & 29 & 36,7 & 14 & 17,7 & 79 & 100 & \\
\hline
\end{tabular}

Pada tabel 18. Menunjukkan bahwa hasil uji chi-square untuk melihat adanya hubungan antara tingkat pengetahuan dengan kepatuhan minum obat antihipertensi bahwa nilai $p$-value $=0,0005$. Dari nilai $\mathrm{p}$ dalam hasil uji statistik didapatkan keputusan Ho ditolak $(\mathrm{p}<0,05)$ yang artinya ada hubungan yang signifikan antara tingkat pengetahuan dengan kepatuhan minum obat antihipertensi. Biasanya seseorang yang berpengetahuan baik tentang penyakit yang diderita akan lebih patuh untuk meminum obat karena mengetahui risiko yang mungkin terjadi apabila tidak meminum obat secara rutin. Pengetahuan pasien yang baik mengenai hipertensi akan memengaruhi kepatuhan pasien dalam meminum obat[15].

\section{KESIMPULAN}

Berdasarkan hasil penelitian tingkat pengetahuan dengan kepatuhan minum obat di Rumah Sakit X Cilacap dapat disimpulkan bahwa terdapat hubungan antara tingkat pengetahuan dengan kepatuhan minum obat pada pasien hipertensi di Rumah Sakit X Cilacap yaitu dengan nilai $\mathrm{p}$-value $=0,005(\mathrm{p}<0,05)$. Nilai tingkat kepatuhan minum obat pada pasien hipertensi di Rumah Sakit X Cilacap yaitu nilai tingkat kepatuhan minum obatnya tinggi sebanyak 45,6\%, kepatuhan minum obatnya sedang sebanyak $36,7 \%$, dan kepatuhan minum obatnya rendah sebanyak $17,7 \%$. Nilai tingkat kepatuhan minum obat berdasarkan kategori pasien diantaranya: jenis kelamin, usia, pekerjaan, pendidikan terakhir, dan lama menderita hipertensi menunjukkan bahwa tidak ada hubungan yang signifikan antara jenis kelamin, usia, pekerjaan, pendidikan dan lama menderita hipertensi dengan kepatuhan minum obat pada pasien hipertensi di Rumah Sakit X Cilacap.

\section{DAFTAR PUSTAKA}

[1] H. R. Pramestutie and N. Silviana, "The Knowledge Level of Hypertension Patients for Drug Therapy in the Primary Health Care of Malang," Indones. J. Clin. Pharm., 2016, doi: 10.15416/ijcp.2016.5.1.26.

[2] N. Aprilla, E. Yahya, and Ririn, "Hubungan Pengetahuan Penderita Hipertensi Tentang Hipertensi Dengan Kepatuhan Minum Obat Antihipertensi Di Wilayah Kerja Puskesmas Kampa Tahun 2019,” J. Ners, 2019.

[3] Dinas Kesehatan Jawa Tengah, "Provinsi Jawa Tengah Tahun 2015," Profil Kesehat. Provinsi Jawa Teng., 2015, doi: 10.1016/j.ajo.2008.04.036.

[4] Sinuraya, et al., "Assessment of Knowledge on Hypertension among Hypertensive Patients in Bandung City: A Preliminary Study," Indones. J. Clin. Pharm., 2017, doi: 10.15416/ijcp.2017.6.4.290.

[5] D. RI, "Buku Pedoman Teknis Penemuan dan Tatalaksana Penyakit Hipertensi," in Physical Review D, 2015.

[6] V. E. Pudjowati and D. W. Widodo, "Nursing News Volume 3, Nomor 1, 2018," 
Nurs. News (Meriden)., 2016.

[7] W. Wijayanto and P. Satyabakti, "Hubungan Tingkat Pengetahuan Komplikasi Hipertensi dengan Keteraturan Kunjungan Penderita Hipertensi Usia 45 Tahun Ke Atas," J. Berk. Epidemiol., 2014.

[8] T. Endang, "Pelayanan keperawatan bagi penderita hipertensi secara terpadu," Pelayanan Keperawatan bagi penderita Hipertens. secara terpadu, 2014, doi: 10.16309/j.cnki.issn.1007-1776.2003.03.004.

[9] M. Yogiantoro, "Pendekatan Klinis Hipertensi," in Buku Ajar Ilmu Penyakit Dalam, 2015.

[10] C. T. Wahyudi, D. Ratnawati, and S. A. Made, "Pengaruh Demografi, Psikososial, Dan Lama Menderita Hipertensi Primer Terhadap Kepatuhan Minum Obat Antihipertensi," J. JKFT, 2018, doi: 10.31000/jkft.v2i1.692.

[11] A. Agrina, S. S. Rini, and R. Hairitama, "Kepatuhan Lansia Penderita Hipertensi Dalam Pemenuhan Diet Hipertensi," SOROT, 2011, doi: 10.31258/sorot.6.1.2001.

[12] Kemenkes RI, "Hasil Utama Riset Kesehatan Dasar 2018," Kementrian Kesehat. Republik Indones., 2018, doi: 1 Desember 2013.

[13] D. Ekarini, "Faktor-Faktor Yang Berhubungan Dengan Tingkat Ke Klien Hipertensi Kepatuhan Dalam Menjalani Pengobatan di Puskesmas Gondangrejo Karanganyar," J. KESMADASKA, 2012.

[14] B. Nuraini, "Risk Factors of Hypertension," J Major., 2015.

[15] M. Bin Mohd Arifin and I. Weta, "Faktor-Faktor Yang Berhubungan Dengan Kejadian Hipertensi Pada Kelompok Lanjut Usia Di Wilayah Kerja Upt Puskesmas Petang I Kabupaten Badung Tahun 2016,” E-Jurnal Med. Udayana, 2016. 